\title{
Estado fresco de morteros y hormigones con arenas de machaqueo
}

\section{Effect of crushed sand on mortar and concrete rheology}

\author{
O. A. Cabrera $^{(*)}$, L. P. Traversa(**), N. F. Ortega ${ }^{(* * *)}$
}

Recepción/Received: 23-X-09

Aceptación/Accepted: 10-XII-10

RESUMEN

En el presente trabajo se plantea un estudio experimental del estado fresco de morteros y hormigones con arenas de machaqueo, orientado a la evaluación de la incidencia de la forma y textura superficial de los granos del árido fino y del contenido de polvo sobre la reología de las mezclas. El programa experimental comprendió el estudio del estado fresco de hormigones con arenas con partículas angulares, la influencia de este tipo de partículas sobre la efectividad de los aditivos químicos y la evaluación de la influencia de las características físicas del árido fino sobre la exudación. Los resultados muestran que el empleo de arenas de machaqueo provoca un comportamiento reológico diferente al de hormigones con arenas naturales, y que el efecto de los aditivos superfluidificantes mejora notablemente este comportamiento.

Palabras clave: arena de machaqueo, arena triturada, forma y textura superficial, estado fresco de hormigones.

\section{SUMMARY}

This article describes an experimental study conducted on fresh mortars and concretes made with crushed sand. The aim of this research was to assess the effect of aggregate particle shape and surface texture as well as dust content on mortar and concrete rheology. The experimental programme also addressed the impact of angular grains on chemical admixture performance and concrete bleeding. The findings showed that the use of crushed sand induces rheological behaviour that differs from the behaviour observed in natural sand and that superplasticisers can improve this behaviour considerably.

Keywords: manufactured sand, crushed sand, shape and surface texture, fresh concrete.

\section{INTRODUCCIÓN}

Debido al agotamiento de yacimientos de arenas o por las restricciones de origen ecológico, cada vez más será necesario encontrar yacimientos de arenas de partículas

\section{INTRODUCTION}

The depletion of sand beds, in conjunction with ecological constraints, is intensifying the need to find sources of sand characterised by hard, strong and stable

(*) Universidad Nacional del Centro de la Provincia de Buenos Aires (Olavarría, Argentina).

(**) LEMIT (La Plata, Argentina).

(***) Universidad Nacional del Sur (Bahía Blanca, Argentina). 
duras, resistentes y estables, libres de impurezas orgánicas y de polvo, que den resultados satisfactorios en los ensayos de durabilidad por ataque con soluciones de sulfato de sodio o magnesio, y que no presenten sustancias nocivas o deletéreas para el hormigón 0 el acero de refuerzo, pero cuyos granos tengan dimensiones tales que satisfagan los requisitos de calidad del hormigón en estado fresco y endurecido. No siempre resulta fácil disponer de fuentes de áridos aptos para el hormigón. En algunas zonas importantes de la República Argentina, como es la provincia de Buenos Aires, la existencia de muy pocos yacimientos de gravas, dadas las características de los ríos pampeanos, hace necesaria la obtención de áridos a partir de la trituración de rocas. Esta situación no difiere de otras regiones a nivel internacional, observándose en muchos países una creciente escasez de áridos naturales (1-7).

El estado fresco de morteros y hormigones comprende el periodo que va desde el momento en que el cemento se pone en contacto con el agua hasta que comienza el fraguado. Durante este tiempo, el material debe tener un comportamiento reológico que permita la adecuada colocación y compactación, que evite la formación de nidos de abeja (oquedades por falta de mortero, honeycomb) y de poros de aire atrapado, que logre el recubrimiento total de las armaduras, obtenga la mínima segregación y exudación, y una buena terminación superficial $(2,8)$. Los defectos que el material pueda incorporar en este periodo repercutirán de manera desfavorable sobre sus propiedades mecánicas, la estabilidad volumétrica y la durabilidad, siendo escasa o nula la posibilidad de revertirlos posteriormente.

La selección de los materiales, la dosificación adecuada a los métodos de colocación y compactación y el grado de control empleado influyen sobre las propiedades del material en estado fresco, siendo la trabajabilidad la propiedad que lo caracteriza. El árido fino, especialmente sus características físicas de tamaño, forma y textura superficial, tienen una influencia importante sobre la trabajabilidad y la demanda de agua y/o el contenido de pasta de las mezclas, siendo éste un punto central cuando se trata de arenas de machaqueo (6). El agua es el principal factor que gobierna la trabajabilidad y un incremento de la misma para producir mezclas trabajables no solo afecta la resistencia al incrementar la porosidad, sino también favorece la segregación y exudación, y diminuye la durabilidad de la estructura.

La relación entre la demanda de agua y la consistencia, que es afectada sensiblemente por la finura, forma y textura del árido fino, es importante en el diseño de mezclas. En ese sentido el Comité ACI 211 (9) incluye esta relación para diferentes tamaños máximos del árido grueso, para hormigones con arenas naturales. En cambio, particles, free of organic impurities and dust. Such sand must perform satisfactorily in durability studies consisting of sodium or magnesium sulfate attacks and contain no substances that might be detrimental to the concrete or reinforcing steel. At the same time, its grain dimensions must ensure that the resulting concrete will meet fresh and hard state requirements. It is not always easy to find sources of aggregate suitable for concrete. The characteristics of Pampean rivers has led to a relative paucity of gravel beds in the Argentinean province of Buenos Aires, for instance, and the concomitant need to manufacture aggregate by crushing rocks. This situation is unexceptional, for natural aggregates are becoming scarce in many countries (1-7).

Mortars and concretes are considered to be fresh from the time the cement and water are mixed until setting begins. In this stage, the material must be fluid enough to ensure proper casting and compaction to prevent the formation of honeycombs or entrained air; cover the reinforcement entirely; ensure minimum segregation and bleeding; and provide a good surface finish $(2,8)$. Any flaws arising in the material during this phase have an adverse impact on the mechanical properties, volumetric stability and durability of the resulting concrete and such flaws are practically impossible to rectify once the material hardens.

Component selection, dosage suited to the placement and compaction methods to be used and quality control affect the properties of fresh concrete, in particular workability. The physical characteristics of fine aggregate, including size, shape and surface texture, have a sizeable effect on workability, water demand and paste content in mixes and that effect is intensified when crushed sand is used (6). Workability is chiefly governed by water content and any increase in the dose to make mixes more workable not only affects strength due to the rise in porosity, but also favours segregation and bleeding and lowers structural durability.

The relationship between water demand and consistency, which is particularly sensitive to aggregate fineness, shape and texture, is instrumental in mix design. ACI Committee 211 (9) establishes a scale for maximum coarse aggregate size in concretes made with natural sand. The British standard on dosage, in turn, 
el método de dosificación británico indica una relación similar para mezclas que contienen arenas de machaqueo (10). Adicionalmente, Popovics (11) propuso una expresión general, Ecuación [1], que vincula la demanda de agua, w, y la consistencia del hormigón, $Y$, medida según un determinado método de ensayo: contains a similar scale for mixes containing crushed sand (10). Popovics (11) proposed a general expression, Equation [1] that relates water demand, $w$, to concrete consistency, $Y$, measured as recommended in a given test method:

$$
Y=C \cdot w^{n}
$$

donde: $C$ es una constante que depende del tipo y composición de la mezcla, y $n$ es un exponente que depende del tipo de ensayo utilizado, y que por ejemplo para el ensayo de asentamiento vale 10 (11).

Otros estudios (11) llevaron a la formulación de la Ecuación [2], con un grado mayor de complejidad que la anterior, para obtener la demanda de agua en función de un número importante de variables que inciden en el estado fresco el hormigón, que en definitiva dificultan su empleo. El empleo de esta ecuación presenta las siguientes limitaciones: contenido de cemento entre $180 \mathrm{y}$ $550 \mathrm{~kg} / \mathrm{m}^{3}$, tamaño máximo del árido entre 5 y $150 \mathrm{~mm}$, rango de consistencia de 2,0 a $17,5 \mathrm{~cm}$, y para mezclas sin aditivos. where $C$ is a constant that depends on the type and composition of the mix and $n$ an exponent that depends on the type of test used, with a value for the slump test, for instance, of 10 (11).

Other authors (11) have formulated more complex expressions, such as Equation [2], to obtain the water demand in terms of a substantial number of variables that have an adverse impact on fresh concrete rheology. This equation only holds where the following conditions are met: the cement content must range from 180 to $550 \mathrm{~kg} / \mathrm{m}^{3}$, the maximum aggregate size from 5 to 150 $\mathrm{mm}$, and consistency from 2.0 to $17.5 \mathrm{~cm}$, and the concrete must contain no admixtures.

$$
\begin{gathered}
W=c \cdot(S / 4)^{0.1} \cdot\left[1+3 \cdot 10^{-5}(c-170) \cdot(p-26)\right] \cdot(-0.347 \cdot \log D+1.025) \\
\left\{0.1+\left[\left(0.032 \cdot\left(\left(2^{m}-60\right)^{2}+6570\right)\right] /[c-100]\right\}\right.
\end{gathered}
$$

donde: $w$ es la demanda de agua $\left(\mathrm{lb} / \mathrm{yd}^{3}\right), c$ es el contenido de cemento $\left(\mathrm{lb} / \mathrm{yd}^{3}\right.$ ), $S$ es el asentamiento (pulgadas), $p$ es la demanda de agua para la pasta de consistencia normal (\% en peso), $D$ es el tamaño máximo del árido (pulgadas), y $m$ es el módulo de finura.

Experiencias más recientes (12) orientadas al estudio de hormigones de alta performance, proponen fórmulas de un modelo cuantitativo sobre el comportamiento reológico de morteros con humos de sílice (silica-fume) que describe la resistencia a fluir de mezclas con diferentes tamaños de granos de arena natural cuarzosa, empleando un reómetro. Los tamaños de partículas estuvieron comprendidos entre 75 y $2.000 \mu \mathrm{m}$, y se concluyó que la fracción 75-1.000 um gobierna la fluidez del mortero, a través de la superficie específica y de los mecanismos de fijación del agua. Por encima de este rango de tamaños, las fuerzas de fricción resultantes del equilibrio entre las fuerzas gravitacionales y de flotabilidad parecen ser las que gobiernan los parámetros reológicos.

Además, cuando el tamaño y la textura de las partículas cambian, los puntos de contacto entre ellas también lo hacen. De este modo, la forma y textura superficial de las partículas del árido fino son las
In this expression, $w$ is the water demand $\left(I b / y d^{3}\right), c$ the cement content $\left(\mathrm{Ib} / \mathrm{yd^{3 }}\right), S$ slump (in inches), $p$ water demand for normal consistency paste (\%wt), $D$ the maximum aggregate size (inches) and $m$ the fineness modulus.

A recent study (12) on high performance concretes proposed a quantitative model to define the rheological behaviour of mortars containing silica fume, calibrated by measuring the flow resistance of mixes containing natural quartz sand of different particle sizes with a rheometer. The particle sizes studied ranged from 75 to $2000 \mu \mathrm{m}$ and the conclusion reached was that in the 751000- $\mu m$ range, mortar flowability is governed by specific surface and surface phenomena of water retention. In larger sizes, the mechanism governing rheological parameters appears to be the friction resulting from the equilibrium between the gravitational forces and floatability.

Moreover, changes in particle size and texture change the number of contact points between them. Fines shape and surface texture are, then, primarily responsible for the internal mechanical friction in mortars and concretes 
responsables principales de la fricción mecánica interna de morteros y hormigones, y por ende, de la demanda de agua o del contenido de pasta necesaria para obtener una mezcla plástica. También, otros estudios (13) indican que para agregados finos porosos y con partículas de forma no esférica, la determinación del estado saturado y superficie seca por medio del método del cono (ASTM C-128) (14) se ve afectado por la fricción entre partículas y a su vez modifica la demanda de agua de las mezclas. Como regla general los áridos compuestos por partículas esféricas y lisas permiten obtener hormigones más trabajables. El empleo de arenas de machaqueo como único árido fino trae aparejado teóricamente los siguientes factores:

- cambios en la reología de las mezclas respecto a aquellas fabricadas con arenas naturales, ante la modificación de la forma y textura superficial de las partículas de árido fino;

- necesidad de un mayor contenido de agua y/o de pasta para obtener una trabajabilidad similar;

- efecto sobre la acción de los aditivos químicos;

- modificaciones en el fenómeno de exudación.

El objetivo del presente trabajo fue el estudio del estado fresco de morteros y hormigones elaborados con arena de machaqueo, y su comparación con el comportamiento de hormigones elaborados con arenas naturales. Se evaluaron y analizaron las variables que influyen sobre la consistencia, la acción de diferentes aditivos químicos y el fenómeno de exudación en mezclas con arenas de machaqueo.

\section{MATERIALES Y PROCEDIMIENTO EXPERIMENTAL}

En esta investigación se diseñaron tres experiencias diferentes, donde se empleó un cemento portland normal CPN-40 (Norma IRAM 50000 (15), equivalente al cemento Tipo I (ASTM C-150) (16), con una densidad de 3,13 y una superficie específica Blaine de $310 \mathrm{~m}^{2} / \mathrm{kg}$ ), una piedra granítica de machaqueo $6-20 \mathrm{~mm}$ como árido grueso (PPG) (con densidad de 2,66, factor de cubicidad de 0,92 (17) y coeficiente de lajosidad de 17 (18)), y diferentes áridos finos para efectuar las comparaciones necesarias.

Durante todo el trabajo experimental se utilizaron 6 tipos de arenas: tres graníticas de machaqueo ( $A G-1, A G-2$ y $A G-3)$, una arena dolomítica de machaqueo (AD-1), y dos tipos de arenas naturales ( $A N-1$ y $A N-2)$. Las propiedades físicas de las arenas se pueden ver en la Tabla 1 y Figura 1. and consequently for the water demand or paste content needed to obtain a plastic mix. Some authors (13) maintain that in porous fines with non-spherical particles, findings on saturation and dry surface determined with a slump cone (ASTM C-128) (14) are affected by inter-particle friction, which also modifies water demand in the mixes. As a general rule, aggregates consisting of smooth, spherical particles yield more workable concretes. The use of crushed sand as the sole fine aggregate theoretically entails:

- differences in mix rheology with respect to mixes made with natural sand due to the modification of the shape and surface texture of the fines;

- a need for a higher water or paste content to obtain similar workability;

- changes in the effectiveness of chemical admixtures;

- changes in bleeding.

The present study aimed to analyse fresh mortars and concretes made with crushed sand and compare their behaviour to the performance of concretes made with natural sand. The variables affecting consistency, the action of chemical admixtures and bleeding were assessed in mixes prepared with crushed sand.

\section{MATERIALS AND EXPERIMENTAL PROCEDURE}

Three experiments were designed for this study, using ordinary CPN-40 Portland cement (IRAM standard 50000) (15), equivalent to type I (ASTM C-150) (16) cement, with a density of 3.13 and a Blaine fineness of $310 \mathrm{~m}^{2} / \mathrm{kg}$ ); 6-20- $\mathrm{mm}$ crushed granite aggregate (PPG) with a density of 2.66, cubicity of 0.92 (17) and a plating factor of 17 (18); and different types of fines.

Six types of sand were used: three crushed granites (AG-1, AG-2 and AG-3), a crushed dolomite (AD-1) and two types of natural sand ( $A N-1$ and $A N-2)$. The physical properties of the sands are shown in Table 1 and Figure 1. 
Tabla 1 / Table 1

Clasificación de la forma y textura, y otras características de los áridos finos.

Fine aggregates classification of shape and texture, and other characteristics.

\begin{tabular}{|c|c|c|c|c|c|c|}
\hline \multirow[t]{2}{*}{ Árido fino / Sand } & \multicolumn{3}{|c|}{ Granítica / Granitic (*) } & \multirow{2}{*}{$\begin{array}{c}\text { Dolomítica I } \\
\text { Dolomitic (*) }\end{array}$} & \multicolumn{2}{|c|}{$\begin{array}{l}\text { Arena natural / } \\
\text { Natural sand }\end{array}$} \\
\hline & $A G-1$ & AG-2 & AG-3 & & $A N-1$ & $A N-2$ \\
\hline Módulo de finura / Fineness modulus (Norma IRAM 1505) (22) & 2.37 & 3.33 & 2.67 & 3.38 & 3.33 & 2.48 \\
\hline Contenido de polvo / Dust content, (\%) (Norma IRAM 1540) (23) & 14 & 0 & 10 & 13.3 & 0 & 0.5 \\
\hline Densidad / Density (Norma IRAM 1520) (24) & 2.65 & 2.68 & 2.64 & 2.77 & 2.64 & 2.64 \\
\hline Absorción / Absorption (\%) (Norma IRAM 1520) & 0.20 & 0.18 & 0.20 & 0.25 & 0.10 & 0.15 \\
\hline Densidad a granel suelta / Loose unit weight, $\left(\mathrm{kg} / \mathrm{m}^{3}\right)$ & 1566 & 1535 & 1400 & 1551 & 1724 & 1604 \\
\hline $\begin{array}{l}\text { Densidad a granel compactada / Compacted unit weight }\left(\mathrm{kg} / \mathrm{m}^{3}\right) \\
\text { (Norma IRAM 1548) (25) }\end{array}$ & 1813 & 1653 & 1716 & 1745 & 1803 & 1710 \\
\hline Forma de las partículas / Particle shape, (BS 812) & \multicolumn{3}{|c|}{ Angular / Angular } & $\begin{array}{l}\text { Elongada / } \\
\text { Elongated }\end{array}$ & \multicolumn{2}{|c|}{$\begin{array}{l}\text { Redondeada / } \\
\text { Rounded }\end{array}$} \\
\hline Textura superficial / Surface texture, (BS 812) & \multicolumn{3}{|c|}{ Cristalina / Crystalline } & Rugosa / Rough & \multicolumn{2}{|c|}{ Lisa / Smooth } \\
\hline
\end{tabular}

$\left(^{*}\right)$ Arena de machaqueo / Crushed sand.

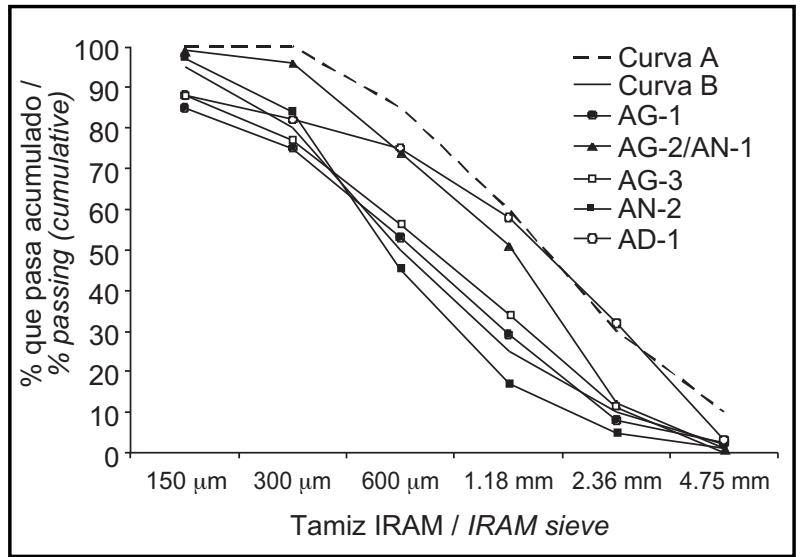

Figura 1. Curvas granulométricas de las arenas para morteros y hormigones.

Figure 1. Grading of sands for mortars and concretes.

En primer término, con el fin de evaluar comparativamente las recomendaciones ACI y BS se elaboró una serie de 42 mezclas de hormigones con arena de machaqueo granítica $A G-1$, cuyas proporciones se detaIlan en la Tabla 2. Complementariamente, se realizó una serie de tres mezclas (Tabla 3) con arena de machaqueo dolomítica $(A D-1)$ dado que la forma de las partículas de este tipo de arena era más elongada que en el caso de la arena granítica. De este modo se evaluaron comparativamente las demandas de agua de hormigones con arena de tres tipos de forma, redondeada, angular y elongada.

En la segunda etapa, destinada a evaluar el efecto de la morfología de los granos de arena sobre la acción de los aditivos químicos, se elaboraron dos series de morteros con arenas de machaqueo granítica $A G-2$ (Serie $A T$ ) y natural silícea $A N-1$ (Serie $A N$ ), de idéntico módulo de finura y sin polvo, con relación "cemento arena", en peso
For the first stage of the study, a series of 42 concrete mixes were prepared with crushed granite sand, batched as specified in Table 2, to compare the ACI and BS recommendations. In addition, a series of three mixes (Table 3) were prepared with crushed dolomite sand $(A D-1)$, for the particles in this type of sand were more elongated than in the granite sand. In this stage, then, water demand was evaluated in concrete made with sand whose particles were rounded, angular or elongated.

In the second stage, intended to assess the effect of sand grain morphology on chemical admixture behaviour, two series of mortars were prepared with dust-free crushed granite AG-2 (series $A T$ ) and natural siliceous sand $A N-1$ (series $A N$ ) with identical fineness moduli. The cement/sand ratio (wt) was $1: 3$ and the 
de "1:3" y relación agua/cemento $(a / c)$ de 0,50 . Las proporciones de los morteros fueron de $500 \mathrm{~g}$ de cemento, $1.500 \mathrm{~g}$ de arena, $250 \mathrm{~g}$ de agua, y las cantidades de aditivos usadas en cada pastón se indican en la Tabla 4, para las Series $A N$ y $A T$. Con el fin de obtener un panorama general de los principales aditivos se emplearon un incorporador de aire, un plastificante-acelerante de endurecimiento y un superfluidificante. water/cement ratio 0.50 . The mortar proportions were $500 \mathrm{~g}$ of cement, $1500 \mathrm{~g}$ of sand, $250 \mathrm{~g}$ of water and the amounts of admixture specified in Table 4 for series $A N$ and AT. An air-entraining, a plasticising-accelerating or a superplasticising admixture was included in the mixes to explore the behaviour of the main types of concrete additives in these mixes.

Tabla 2 / Table 2

Dosificaciones de hormigones con arena de machaqueo granítica, en $\mathrm{kg} / \mathrm{m}^{3}$.

Dosage for crushed granitic sand concretes, in $\mathrm{kg} / \mathrm{m}^{3}$.

\begin{tabular}{|c|c|c|c|c|c|c|c|c|c|}
\hline $\begin{array}{l}\text { Mezcla } n^{\circ} / \\
\text { Mix } n^{\circ}\end{array}$ & $C P N$ & $\begin{array}{c}\text { Agua I } \\
\text { Water }\end{array}$ & $A G-1$ & PPG & $\begin{array}{c}\text { Mezcla } n^{\circ} / \\
{\text { Mix } n^{\circ}}^{\circ}\end{array}$ & $C P N$ & $\begin{array}{l}\text { Agua I } \\
\text { Water }\end{array}$ & $A G-1$ & $P P G$ \\
\hline 1 & 483 & 232 & 822 & 771 & 22 & 325 & 215 & 848 & 960 \\
\hline 2 & 464 & 251 & 817 & 778 & 23 & 314 & 220 & 806 & 960 \\
\hline 3 & 460 & 230 & 657 & 960 & 24 & 320 & 214 & 760 & 1055 \\
\hline 4 & 418 & 230 & 692 & 960 & 25 & 300 & 249 & 1041 & 694 \\
\hline 5 & 420 & 218 & 670 & 1009 & 26 & 304 & 225 & 827 & 972 \\
\hline 6 & 417 & 238 & 800 & 871 & 27 & 300 & 225 & 806 & 960 \\
\hline 7 & 400 & 256 & 983 & 655 & 28 & 296 & 240 & 950 & 843 \\
\hline 8 & 403 & 242 & 776 & 887 & 29 & 300 & 213 & 774 & 1057 \\
\hline 9 & 400 & 236 & 896 & 795 & 30 & 300 & 210 & 663 & 1179 \\
\hline 10 & 400 & 216 & 730 & 1014 & 31 & 275 & 220 & 840 & 960 \\
\hline 11 & 400 & 216 & 784 & 960 & 32 & 268 & 217 & 975 & 849 \\
\hline 12 & 400 & 212 & 632 & 1124 & 33 & 250 & 245 & 1075 & 717 \\
\hline 13 & 366 & 220 & 763 & 960 & 34 & 246 & 226 & 1000 & 821 \\
\hline 14 & 362 & 224 & 898 & 826 & 35 & 250 & 215 & 912 & 960 \\
\hline 15 & 350 & 250 & 1016 & 677 & 36 & 250 & 215 & 673 & 1197 \\
\hline 16 & 352 & 229 & 908 & 804 & 37 & 244 & 227 & 975 & 864 \\
\hline 17 & 350 & 227 & 757 & 960 & 38 & 250 & 210 & 796 & 1086 \\
\hline 18 & 350 & 235 & 919 & 814 & 39 & 248 & 203 & 851 & 1031 \\
\hline 19 & 350 & 217 & 754 & 1029 & 40 & 225 & 270 & 1040 & 700 \\
\hline 20 & 347 & 212 & 772 & 1011 & 41 & 235 & 228 & 827 & 1022 \\
\hline 21 & 350 & 210 & 648 & 1152 & 42 & 225 & 216 & 790 & 1100 \\
\hline
\end{tabular}

Tabla 3 / Table 3

Dosificaciones de hormigones con arena de machaqueo dolomítica, en $\mathrm{kg} / \mathrm{m}^{3}$.

Dosage for crushed dolomitic sand concretes, in $\mathrm{kg} / \mathrm{m}^{3}$.

\begin{tabular}{|c|c|c|c|c|}
\hline Mezcla $^{\mathbf{0}} /$ Mix $^{\mathbf{0}}$ & CPN & Agua / Water & AD-1 & PPG \\
\hline D-1 & 350 & 225 & 762 & 1030 \\
\hline D-2 & 400 & 230 & 705 & 1030 \\
\hline D-3 & 450 & 225 & 674 & 1030 \\
\hline
\end{tabular}

Tabla 4 / Table 4

Dosis de aditivos en \% del peso de cemento, y en gramos c/2.250 gramos de mortero.

Dosis of admixture in \% by weight of cement, and in grams per 2250 grams of mortar.

\begin{tabular}{|c|c|c|c|c|c|c|c|c|}
\hline \multicolumn{3}{|c|}{$\begin{array}{c}\text { Dosis de incorporador de aire I } \\
\text { Air-entraining dosage }\end{array}$} & \multicolumn{3}{c|}{ Dosis de plastificante / Plasticizer dosage } & \multicolumn{3}{c|}{$\begin{array}{c}\text { Dosis de superfluidificante I } \\
\text { Superplasticizer dosage }\end{array}$} \\
\hline$\%$ CPN & AN (g) & AT (g) & \% CPN & AN (g) & AT (g) & $\%$ CPN & AN (g) & AT (g) \\
\hline 0.00 & 0 & 0 & 0.00 & 0.0 & 0.0 & 0.0 & 0.0 & 0.0 \\
\hline 0.05 & 0.25 & - & 0.23 & 1.15 & - & 1.0 & 5.0 & - \\
\hline 0.10 & 0.5 & - & 0.44 & 0.22 & - & 2.0 & 10.0 & 10.0 \\
\hline 0.17 & 0.85 & 0.85 & 1.00 & 5.00 & 5.00 & 3.0 & 15.0 & - \\
\hline 0.20 & 1.00 & - & 1.50 & 7.50 & - & 4.0 & - & 20.0 \\
\hline 0.34 & 1.70 & 1.70 & 2.00 & - & 10.0 & 6.0 & - & 30.0 \\
\hline 0.66 & - & 3.30 & 3.00 & - & 15.0 & - & - & - \\
\hline
\end{tabular}


Para completar el estudio del comportamiento del estado fresco, y analizar cómo influye la forma y textura del árido fino en el contenido de pasta del hormigón, en la tercera etapa, se diseñaron otras series de hormigones con relaciones $a / c 0,46,0,51,0,59$ y 0,67 (Tabla 5). Se emplearon dos arenas, $A N-2$ (Serie $N$ ) y $A G-3$ (Serie $T$ ), con curvas granulométricas cercanas a la curva límite inferior de la Norma ASTM C-33 (19), módulos de finura similares y características físicas extremas respecto a su efecto sobre la reología del hormigón fresco. El contenido de polvo de la arena $A G-3$ fue del $10 \%$, en cambio la arena $A N-2$ prácticamente no contenía polvo (Tabla 1). Las mezclas presentaron una consistencia de $8 \pm 1,5 \mathrm{~cm}$, y los ensayos de exudación se realizaron de acuerdo con la Norma IRAM 1604 (20).

En general, las arenas de machaqueo se emplearon sin lavar sobre el tamiz de $75 \mu \mathrm{m}$ a fin de evaluar su utilización tal como proceden de la planta de machaqueo. En el caso eliminar el polvo de las arenas $A G-1$ y $A G-3$ sus curvas granulométricas se ajustan a los límites de la Norma ASTM C-33. La arena $A N-1$ procede de la mezcla de dos arenas naturales, y la $A N-2$ es una arena de uso generalizado y con un comportamiento satisfactorio. En la Tabla 1 se indican las características físicas, y la clasificación de la forma y textura superficial de las partículas de las arenas en estudio, de acuerdo con la Norma BS 812 (21). En la Figura 1 se indican las curvas granulométricas de las arenas empleadas y las curvas límites A y B de la Norma ASTM C-33.
In the third stage, additional series of concretes with $\mathrm{w} / \mathrm{c}$ ratios of $0.46,0.51,0.59$ and 0.67 (Table 5) were prepared to analyse the effect of fines shape and texture on concrete paste content. Two types of sand, $A N-2$ (series $N$ ) and AG-3 (series T) were used, with particle size distribution curves close to the lower limit specified in ASTM C-33 (19), similar fineness moduli and physical shapes that were diametrically opposed in terms of their effect on fresh concrete rheology. Moreover, the dust content in sand AG-3 was $10 \%$, while sand $A N-2$ was practically dust-free (Table 1). The mixes had a consistency of $8 \pm 1.5 \mathrm{~cm}$ and the bleeding trials were conducted as described in standard IRAM 1604 (20).

As a rule, sand is sieved in a 75- $\mu m$ sieve prior to washing to assess its usability as supplied by the crushing plant. When the dust was removed from sands AG-1 and AG-3, their particle size distribution curves were within the limits specified in ASTM C-33. Sand AN1 was the result of mixing two natural sands, while $A N$ 2 is a sand routinely used with satisfactory results. Table 1 gives the physical characteristics and particle shape and surface texture classification of the sands used in the study, pursuant to BS 812 (21). Figure 1 compares the particle size distribution curves for the sands used to the curves defining the acceptable range according to ASTM C-33.

Tabla 5 / Table 5

Dosificaciones de hormigones con arenas natural $(\mathrm{N})$ y granítica de machaqueo $(T)$, en $\mathrm{kg} / \mathrm{m}^{3}$.

Dosage for natural sand concretes $(N)$, and crushed granitic sand concretes $(T)$, in $\mathrm{kg} / \mathrm{m}^{3}$.

\begin{tabular}{|c|c|c|c|c|c|c|c|c|c|}
\hline $\begin{array}{l}\text { Mezcla } n^{\circ} / \\
\operatorname{Mix} n^{\circ}\end{array}$ & CPN & $\begin{array}{l}\text { Agua I } \\
\text { Water }\end{array}$ & AN-2 & PPG & $\begin{array}{c}\text { Mezcla } n^{\circ} / \\
\operatorname{Mix} n^{\circ}\end{array}$ & CPN & $\begin{array}{l}\text { Agua I } \\
\text { Water }\end{array}$ & AG-3 & PPG \\
\hline $\mathrm{N}-46$ & 350 & 160 & 840 & 1050 & T-46 & 450 & 205 & 640 & 1050 \\
\hline $\mathrm{N}-51$ & 315 & 160 & 870 & 1050 & $T-51$ & 400 & 205 & 680 & 1050 \\
\hline $\mathrm{N}-59$ & 270 & 160 & 910 & 1050 & T-59 & 350 & 205 & 723 & 1050 \\
\hline $\mathrm{N}-67$ & 250 & 167 & 910 & 1050 & T-67 & 300 & 200 & 778 & 1050 \\
\hline
\end{tabular}

\section{RESULTADOS EXPERIMENTALES}

A continuación se presentan los resultados obtenidos de la primera Serie de hormigones destinados a evaluar el estado fresco de los mismos con áridos finos graníticos de machaqueo. En la Figura 2 se muestran los valores medidos del asentamiento en función de la demanda de agua, y se comparan con los valores que establecen el Comité ACI 211 (9) para hormigones con arenas naturales y la Norma BS para hormigones con arenas de machaqueo.

El estado fresco del hormigón queda definido por algunas variables que tienen un fuerte impacto sobre la trabajabilidad, entre ellas se encuentran la demanda de agua, Ecuación [1], y las relaciones a/c y árido/cemento, donde esta última refleja la cantidad de pasta necesaria

\section{EXPERIMENTAL RESULTS}

The findings for the first series of concretes, made with crushed granite fines, are set out below. Figure 2 shows the slump values versus the water demand and compares these results to the values established by ACI Committee 211 (9) for concrete made with natural sand as well as to the values laid down in the BS standard for concrete made with crushed sand.

Fresh concrete rheology is defined by variables with a heavy impact on workability, including water demand, Equation [1], the $w / c$ ratio and the aggregate/cement ratio, a measure of the amount of paste required to lubricate the aggregate particles. The amount of paste, 
para lubricar las partículas de áridos. A su vez, la cantidad de pasta depende de la finura del cemento, y del tamaño y características superficiales de los áridos. Algunos autores (26-27) han establecido una relación árido/cemento normalizada, es decir, que este parámetro se relativiza con el correspondiente al de una dosificación de hormigón con relación $a / c$ 0,50. in turn, depends on cement fineness and aggregate size and surface characteristics. Some authors (26-27) have established a normalised aggregate/cement ratio, i.e., referring this parameter to the value for concrete prepared with a $w / c$ ratio of 0.50 .

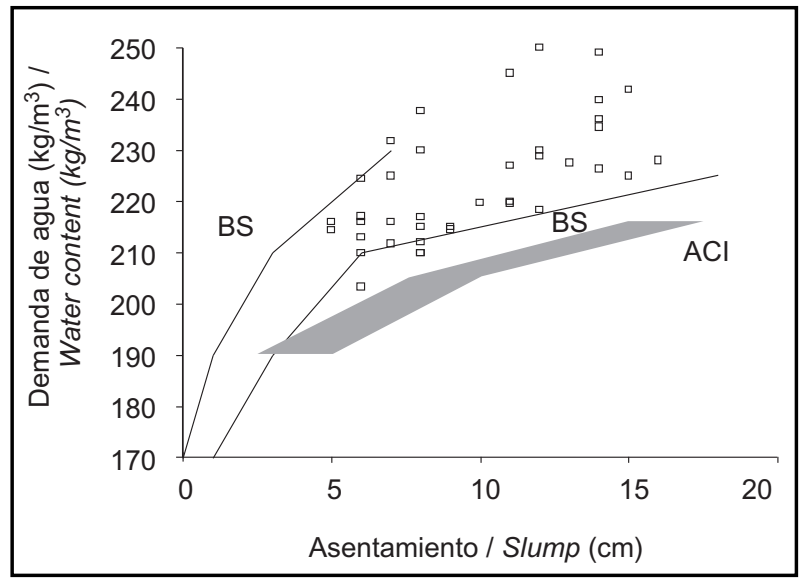

Figura 2. Relación entre la demanda de agua y el asentamiento para hormigones con arena de machaqueo granítica. Figure 2. Relationship between the water content and the slump for concretes with crushed granitic sand.

Los valores experimentales de las mezclas de la primera Serie, también incluidos en la Figura 2, con arena de machaqueo granítica $A G-1$ se utilizaron para obtener la relación árido/cemento normalizada, y vincularla con la relación $a / c$. Los valores calculados se agruparon en dos rangos de consistencia, $7 \pm 2$ y $13 \pm 2 \mathrm{~cm}$, definiendo dos rectas con altos coeficientes de regresión, que permiten analizar en forma clara la interrelación entre las variables mencionadas (Figura 3).
The experimental values for the first series of mixes made with crushed granite AG-1, shown in Figure 2, were used to obtain the normalised aggregate/cement ratio and relate it to the $w / c$ ratio. The values calculated were grouped in two consistency ranges, $7 \pm 2$ and $13 \pm 2$ $\mathrm{cm}$, and regression lines with high coefficients of determination were defined to analyse the relationship between these two variables Figure 3).

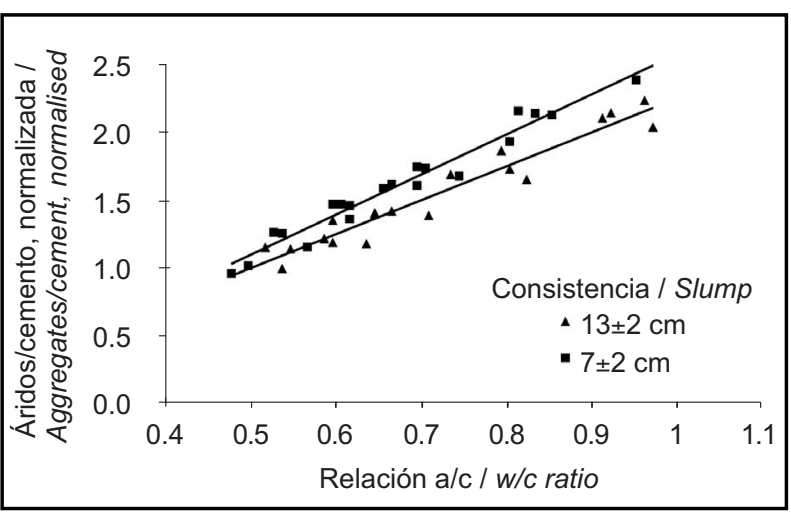

Figura 3. Influencia de las relaciones árido/cemento y agua/cemento sobre la consistencia del hormigón $\left(R^{2}=0,93-0,96\right)$. Figure 3. Influence of the relations aggregate/cement and water/cement on the concrete consistency $\left(R^{2}=0.93-0.96\right)$.

Por otra parte, los resultados de la demanda de agua obtenidos con la serie de hormigones con arena de machaqueo dolomítica se indican en la Tabla 6 , y se comparan con valores para arena granítica y natural, para diferentes rangos de consistencia.
The water demand findings for the crushed dolomite sand concretes are given in Table 6, where they are compared to the values for granite and natural sand materials for different consistency ranges. 
Tabla 6 / Table 6

Demanda de agua $\left(\mathrm{kg} / \mathrm{m}^{3}\right)$ vs. asentamiento para hormigones con diferentes tipos de arenas. Water content $\left(\mathrm{kg} / \mathrm{m}^{3}\right)$ vs. slump for concretes with different types of sands.

\begin{tabular}{|c|c|c|c|c|}
\hline \multirow{2}{*}{ Asentamiento / Slump (cm) } & \multirow{2}{*}{$\begin{array}{c}\text { Rango de consistencia (ACI 211) / } \\
\text { Consistency description (ACl 211) }\end{array}$} & \multicolumn{2}{|c|}{ Hormigón elaborado con arena / Concrete with sand } \\
\cline { 3 - 5 } & & Dolomítica / Dolomitic & Granítica / Granitic & $\begin{array}{c}\text { Natural (ACl 211) / } \\
\text { Natural (ACl 211) }\end{array}$ \\
\hline $0-5.0$ & Seca / Stiff & $200-218$ & 215 & 190 \\
\hline $7.5-10.0$ & Plástica / Plastic & $225-230$ & 225 & 205 \\
\hline $15.0-17.5$ & Fluida / Very plastic & 248 & 240 & 216 \\
\hline
\end{tabular}

En la segunda parte experimental de este trabajo, el empleo de aditivos químicos en hormigones con diferentes tipos de arenas para mejorar la reología de las mezclas frescas y controlar la demanda de agua es una posibilidad tecnológica importante; pero debe recordarse que el efecto y la dosis de los aditivos están fuertemente influenciados por las características físicas (tamaño, forma y textura superficial) de las partículas del árido fino (28-30). Los resultados de los ensayos de fluidez (31) y del contenido de aire incorporado de los morteros (32), con diferentes tipos y dosis de aditivos se indican en las Figuras 4.a-c.
The use of chemical admixtures in concretes with different types of sand to improve fresh mix rheology and control water demand is an important technological achievement. Since admixture effect and dosage are highly dependent on the physical characteristics (size, shape and surface texture) of fines (28-30), the second stage of this study explored this relationship. The flowability (31) and entrained air content in mortars (32) with different admixture types and dosages are shown in Figures 4.a-c.

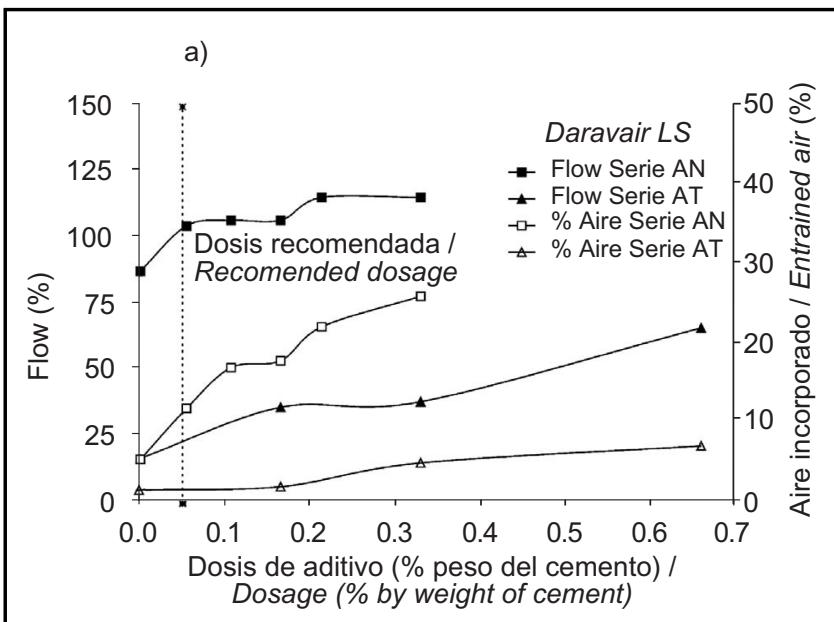

b)

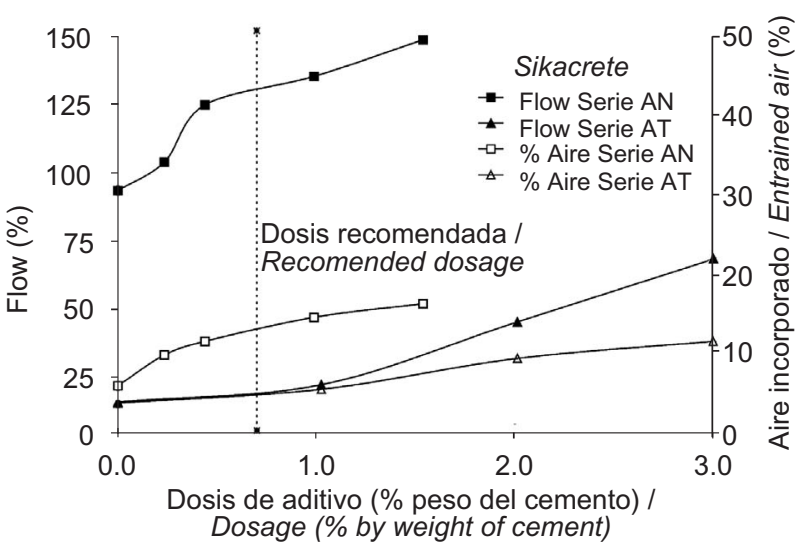

c)

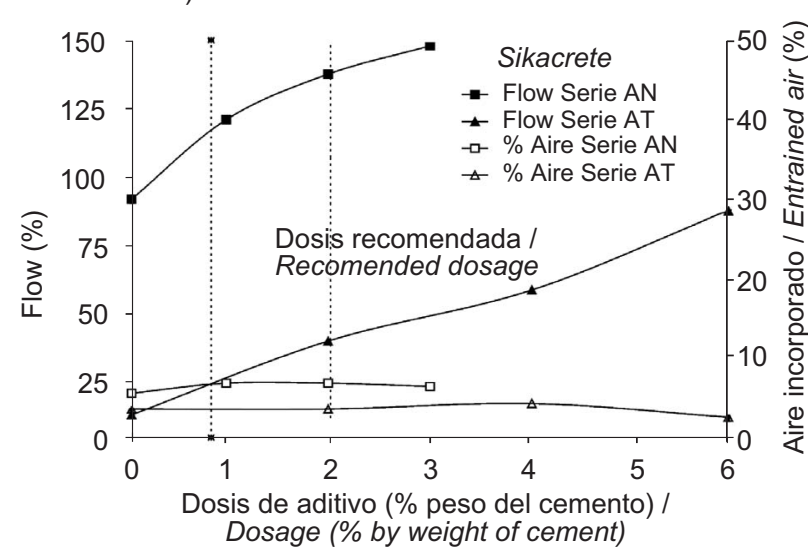

Figura 4. a) Efecto de aditivos químicos sobre el estado fresco de morteros: incorporador de aire. b) Efecto de aditivos químicos sobre el estado fresco de morteros: plastificante. c) Efecto de aditivos químicos sobre el estado fresco de morteros: superfluidificante.

Figure 4. a) Effect of chemical admixture on the fresh mortars: air-entraining. b) Effect of chemical admixture on the fresh mortars: plasticizer. c) Effect of chemical admixture on the fresh mortars: superplasticizer. 
Finalmente, en las Figuras 5 y 6 se informa de los resultados obtenidos en la tercera etapa experimental relacionados con los contenidos de pasta de las mezclas para el rango de consistencia definido $(8 \pm 1.5 \mathrm{~cm})$, y los valores de los ensayos de exudación realizados para las Series de hormigones $T$ y $N$. El rango de la demanda de agua de la Serie $T$ fue de $200-205 \mathrm{~kg} / \mathrm{m}^{3}$ y para la Serie $N$, $160-165 \mathrm{~kg} / \mathrm{m}^{3}$.
Lastly, Figures 5 and 6 show the results of the third stage of the experiment, i.e., the paste content in the mixes for the slump range defined $(8 \pm 1.5 \mathrm{~cm})$ and the bleeding test values for concrete series $T$ and $N$. The water demand for series $T$ was $200-205 \mathrm{~kg} / \mathrm{m}^{3}$ and for series $\mathrm{N}, 160-165 \mathrm{~kg} / \mathrm{m}^{3}$.

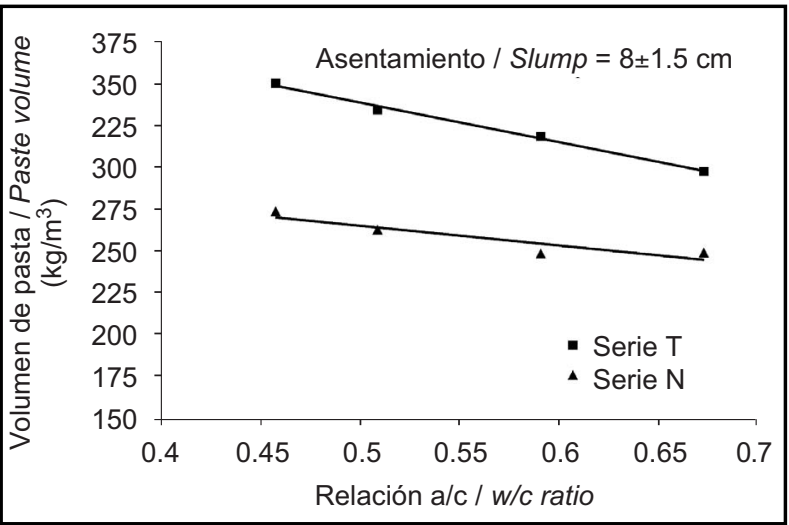

Figura 5. Volumen de pasta para hormigones con arenas natural AN-2 (Serie N) y de machaqueo AG-3 (Serie T) $\left(R^{2}=0.85-0.99\right)$. Figure 5. Paste volume for concretes with natural sand $A N-2$ (Series $N$ ) and crushed sand $A G-3$ (Serie $T)\left(R^{2}=0.85-0.99\right)$.

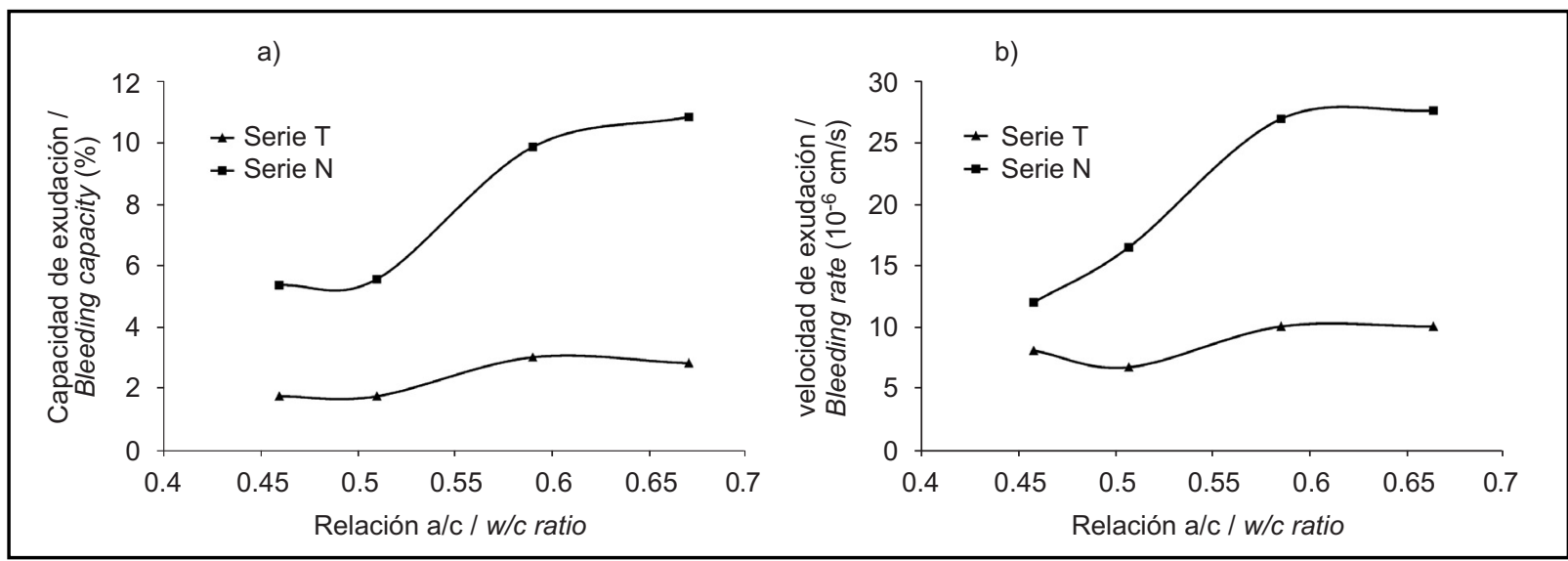

Figura 6. Capacidad (a) y velocidad (b) de exudación de Serie N (AN-2) y la Serie T (AG-3). Figure 6. Capacity (a) and rate (b) of bleeding of Serie $N(A N-2)$ and Serie $T$ (AG-3).

\section{DISCUSIÓN DE LOS RESULTADOS}

\subsection{Efecto de las arenas de machaqueo sobre la demanda de agua y la consistencia del hormigón}

En la Figura 2 se observa que los valores experimentales de los asentamientos de hormigones con arena granítica se ajustan a los límites que establece la Norma BS en su método de dosificación, y se apartan sensiblemente de la zona establecida por el Comité ACI 211 para arenas naturales (zona sombreada).

\section{DISCUSSION}

\subsection{Effect of crushed sand on water demand and concrete consistency}

Figure 2 shows that the experimental slump values for the concrete made with granite sand fell within the limits laid down in the BS standard on batching, but perceptibly outside the area established by ACI Committee 211 for natural sand concretes (shaded area). 
Las experiencias realizadas con hormigones con arenas de machaqueo granítica y dolomítica, con partículas de forma angular y textura superficial cristalina en el caso de la granítica, y elongada y rugosa para la dolomítica, muestran que la demanda de agua para ambas arenas es similar, y se diferencian notablemente de los hormigones con arenas naturales (Tabla 6). Se considera como textura superficial "cristalina" aquella que sus granos contienen constituyentes cristalinos fácilmente visibles; y "rugosa", cuando la fractura rugosa de roca granular fina -o media - tiene constituyentes cristalinos que no se pueden ver fácilmente (21). En términos generales, del análisis de los valores obtenidos se desprende que es necesario incrementar en el orden de $25-30 \mathrm{~kg} / \mathrm{m}^{3}$ de agua en los hormigones con arenas de machaqueo para alcanzar la consistencia de los hormigones con arenas naturales, lo cual se puede traducir en un incremento en el contenido de poros del 2,5-3,0\% del volumen de hormigón endurecido.

En estas experiencias se trabajó con arenas de muy baja absorción, motivo por el que no se ha tenido en cuenta el concepto de agua retenible (water retainability) (13) para realizar ajustes en la demanda de agua de las mezclas. En el trabajo de referencia se utilizaron arenas con valores de absorción $(14,24)$ entre 3,5 y $24 \%$, en cambio las arenas en estudio no superaron el 0,30\%.

Las principales variables que controlan el estado fresco del hormigón se indican en la Figura 3. En ella se muestra la interdependencia entre las relaciones a/c y árido/cemento, y la demanda de agua, dado que para un conjunto determinado de materiales la consistencia está directamente relacionada con la demanda de agua, Ecuación [1]. De la mencionada Figura surge el siguiente análisis que permite mostrar la interdependencia de las tres variables que gobiernan el estado fresco del hormigón, y en este caso particular, elaborado con arena de machaqueo granítica:

- Manteniendo la demanda de agua constante (asentamiento constante), al incrementar la relación árido/cemento, se debe incrementar la relación $a / c$ disminuyendo el contenido de cemento. El hormigón mantendrá la consistencia, aunque la resistencia mecánica disminuirá.

- Manteniendo la relación árido/cemento constante, al incrementar la relación $a / c$ se incrementa la demanda de agua y en consecuencia, el asentamiento. La mezcla será más fluida, y la resistencia del hormigón decrecerá.

- Manteniendo la relación a/c constante, un incremento en la relación árido/cemento se obtiene con la reducción de los contenidos de cemento y agua, y de esta manera, se reduce el asentamiento. La consistencia del hormigón será menos fluida, y su resistencia no se verá afectada sensiblemente.
The experiments conducted with crushed granite (angular particles with a crystalline surface texture) and dolomite (elongated with a rough texture) sand concretes showed that water demand was similar in the two but differed substantially from the values for natural sand (Table 6). Grains were regarded to have a "crystalline" surface texture when they contained readily visible crystalline constituents and a "rough" texture when the crystalline constituents along the rock fracture lines were not readily visible (21). Generally speaking, the analysis of the values found revealed that the water content had to be increased by on the order of 25-30 $\mathrm{kg} / \mathrm{m}^{3}$ in concretes with crushed sand to reach the same consistency as concretes with natural sand. This may translate into a $2.5-3.0 \%$ rise in porosity in the hardened concrete.

Since very low absorption sand was used in these experiments, water retainability (13) was not factored into the calculations to adjust the water demand in the mixes. The absorption values for the sands considered in the standards $(14,24)$ ranged from 3.5 to $24 \%$, whereas the values in the present study were $0.30 \%$ or less.

The variables involved in fresh concrete rheology are shown in Figure 3. Note the interdependence among the $w / c$ and aggregate/cement ratios and water demand, since for a given set of materials consistency was directly related to the third parameter. Equation [1]. The figure reveals the interdependence of the three variables governing fresh concrete rheology, in this case, for materials made with crushed granite sand, which can be summarised as follows.

- To hold the water demand constant (constant slump), if the aggregate/cement ratio is raised, the $w / c$ ratio must also be raised by reducing the amount of cement. The concrete maintains its consistency, although at the expense of mechanical strength.

- Holding the aggregate/cement ratio constant, a rise in the $w / c$ ratio raises water demand and with it, slump. The mix is more fluid although concrete strength declines.

- Holding the w/c ratio constant, the aggregate/cement ratio can be raised by reducing the amounts of cement and water and consequently slump. Concrete consistency is less fluid and its strength is not perceptibly affected. 


\subsection{Efecto de las arenas de machaqueo sobre la acción de los aditivos químicos}

Respecto al empleo de aditivos químicos para reducir los efectos desfavorables en el estado fresco de la forma y textura de las partículas de arena, las Figuras 4.a-c sintetizan los resultados experimentales. Allí se muestra que aún con altas dosis de aditivos de cualquiera de los 3 tipos estudiados, la fluidez de los morteros con arena de machaqueo no alcanza a igualar a la de los elaborados con arena natural.

Respecto a la incorporación de aire por los aditivos químicos, el aditivo incorporador de aire en la dosis recomendada por el fabricante incorporó un $12 \%$ de aire para la Serie $A N$, y un $5 \%$ de aire para los morteros de la Serie $A T$ con una dosis seis veces superior (Figura 4.a). En este último caso no se logró alcanzar el valor recomendado para morteros resistentes a la congelación y deshielo, 9\% (7). En el caso del aditivo plastificante, el mortero con arena natural, con la dosis recomendada, incorporó un $13 \%$ de aire; y los morteros con arena de machaqueo incorporaron un $11 \%$ con una dosis 4 veces superior (Figura 4.b).

Finalmente, el aditivo superfluidificante, que cuya acción principal es evitar la floculación de las partículas de cemento, resultó ser el aditivo que incorpora la menor cantidad de aire, independientemente de la dosis empleada. Los valores de aire incorporado fueron de $\sim 7 \%$ y $\sim 4 \%$ para la Serie $A N$ y $A T$, respectivamente (Figura 4.c).

Se destaca que en las dosis recomendadas por los fabricantes, los aditivos en morteros con arena silícea resultan muy efectivos en la modificación de la fluidez o en la incorporación de aire. En cambio, en morteros con arena de machaqueo granítica el desempeño no es similar, y en algunos casos, un incremento excesivo de la dosis de aditivo puede originar inconvenientes en el fraguado o provocar un importante incremento en la exudación.

Según otras experiencias (33) realizadas por el autor con aditivos químicos, el empleo de arena de machaqueo dolomítica con un contenido mayor de partículas elongadas que la arena granítica, conduce a un comportamiento similar. Se concluye entonces, para ambos tipos de arenas de machaqueo, que para lograr morteros, y también hormigones, con suficiente fluidez es necesario utilizar una dosis de aditivo mayor que cuando se emplean arenas naturales. Además, resulta necesario efectuar un ajuste de las dosificaciones, y establecer si la mayor dosis de aditivo no origina efectos secundarios nocivos para la resistencia o durabilidad del hormigón, como ser una mayor exudación canalizada (efecto champagne), un retardo de fraguado y/o de resistencia, o una mayor porosidad ante un mayor contenido de aire.

\subsection{Impact of crushed sand on the action of chemical admixtures}

The experimental results on the use of chemical admixtures to lower the adverse effects of sand particle shape and texture on fresh concrete rheology are summarised in Figures 4.a-c. As the figures show, even with high dosages of any of the three types of admixture studied, mortars made with crushed sand failed to equal the flowability found in materials made with natural sand.

The manufacturer-recommended dosage of airentraining admixture brought the air content in series $A N$ to $12 \%$, whereas a six-fold higher dose led to only a $5 \%$ content in series AT (Figure 4.a). Consequently, the $9 \%$ recommended value (7) for freeze-thaw-resistant mortars was not reached in the latter series. $A$ recommended dose of the plasticiser brought the air content to $13 \%$ in the natural sand mortar, while with a four-fold greater dose, the air content in the crushed sand materials was 11\% (Figure 4.b).

Lastly, the superplasticiser, used primarily is to prevent cement particle flocculation, had the smallest effect on the air content, regardless of the dose used. The values were $\sim 7 \%$ and $\sim 4 \%$ for series $A N$ and $A T$, respectively (Figure 4.c).

At the manufacturer-recommended doses, the admixtures were highly effective in modifying flowability or entrained air content in mortars with siliceous sand. In mortars made with crushed granite sand, by contrast, they performed less effectively. Moreover, in some cases an excess of admixture may be detrimental to setting or induce a significant rise in bleeding.

Similar observations were recorded in a prior study (33) on the use of chemical admixtures with crushed dolomite sand, which has a higher content of elongated particles than granite sand. The conclusion drawn in that study was that to attain sufficient flowability, a higher dose of admixture was needed in both types of crushed sand than in natural sand concretes. Moreover, dosage had to be adjusted and care taken to ensure that a higher admixture content did not induce adverse side effects on concrete strength or durability, such as channel bleeding, retarded setting or strength development, or greater porosity due to the higher air content. 


\subsection{Efecto de las arenas de machaqueo sobre el volumen de pasta y el fenómeno de exudación del hormigón}

Por otra parte, respecto al volumen de pasta, Domone y Soutos (34) justifican la necesidad de que exista un exceso respecto al contenido de vacíos del conjunto de los áridos para lubricar, dispersar y separar las partículas a fin de brindar plasticidad a la mezcla, especialmente en los hormigones de alta resistencia. Se considera que el exceso de pasta se sitúa alrededor del 3-10\% por encima del volumen de vacíos de los áridos $(35,36)$.

Si el contenido de vacíos es minimizado, la cantidad de pasta requerida para llenar esos vacíos también es minimizada manteniendo la trabajabilidad y la resistencia. Puede plantearse entonces que una óptima dosificación es aquella que produce un hormigón de buena calidad, resistente y durable, con la mínima cantidad de pasta.

Analizando los resultados, en la Figura 5 se indican los volúmenes de pasta necesarios para mantener el rango de consistencia de ambas Series de hormigones, $T$ y $N$, con arenas natural y de machaqueo. El volumen de pasta de los hormigones con arena de machaqueo es del orden del $28 \%$ mayor y la demanda de agua es $45 \mathrm{~kg} / \mathrm{m}^{3}$ mayor respecto a los elaborados con arena natural, para disminuir la fricción interna de las partículas, llenar los espacios entre partículas que en las arenas de machaqueo es superior al de las arenas naturales ( $8 \%)$ con igual granulometría (30), y lubricar el polvo de roca que contienen.

Conceptualmente, los resultados obtenidos coinciden con los de otro trabajo, (6) donde se analizó con otra metodología y equipamiento la influencia de las características de la arena sobre las propiedades reológicas de morteros con áridos graníticos de machaqueo, y se concluyó que el efecto de la forma de la partícula de árido fino incrementa la viscosidad de los morteros como resultado de la interferencia de partículas no esféricas. Este comportamiento se puede reducir incrementando el volumen de pasta de los morteros, o con la incorporación de un aditivo superplastificante que disminuye el umbral de cizallamiento (tensión crítica) y la viscosidad plástica, parámetros que definen el modelo de Bingham.

Los estudios de estas series de hormigones se completó con la evaluación del fenómeno de la exudación de las mezclas que en todos los casos se presentó como uniforme, con valores de velocidad de exudación menores al límite de $100.10^{-6} \mathrm{~cm}^{3} / \mathrm{cm}^{2}$.s establecido para el caso de exudación canalizada (37). Se obtuvo un comportamiento más favorable en los hormigones con arenas de machaqueo, a pesar de la mayor demanda de agua empleada, debido a que la arena de machaqueo poseía

\subsection{Effect of crushed sand on paste volume and concrete bleeding}

Domone and Soutos (34) showed that the volume of paste had to be greater than the volume of voids in the aggregate to lubricate, disperse and separate the particles and ensure mix plasticity, particularly in high strength concretes. The amount of excess paste needed has been estimated to be around $3-10 \%(35,36)$.

If the void content is minimised, the amount of paste required to fill these voids is likewise minimised and workability and strength maintained. The optimal dose may consequently be regarded to be the dose that yields a strong, high quality and durable concrete with the minimum amount of paste.

Figure 5 shows the volume of paste required to maintain the consistency range in concrete series $T$ and $N$ with natural and crushed sand. The volume of paste needed to lower the internal friction in the particles, fill the interstitial spaces and lubricate the rock dust, which is around $8 \%$ higher in crushed than in natural sand with the same particle size distribution, was on the order of $28 \%$ higher in crushed sand than in natural sand concrete, while the water demand was $45 \mathrm{~kg} / \mathrm{m}^{3}$ greater in the former (30).

Conceptually, these findings are consistent with the results of another study (6) where a different methodology and apparatus were used to analyse the effect of sand characteristics on the rheology of mortars with crushed granite sand. There the conclusion drawn was that fine aggregate particle shape raised mortar viscosity due to the interference of non-spherical particles. This behaviour can be corrected by raising the paste volume in mortars or adding a superplasticiser to lower the shear threshold (critical stress) and plastic viscosity, the parameters that define the Bingham model.

The bleeding assessment conducted showed that all the concretes behaved similarly, with values lower than the $100 \cdot 10^{-6} \mathrm{~cm}^{3} / \mathrm{cm}^{2} \cdot \mathrm{s}$ limit established for channel bleeding (37). Performance was better in crushed sand concretes despite the higher water demand because the rougher texture of the crushed sand increased its specific surface (35), as did the $1 \%$ dust content. Moreover, in these cases the dosages had a higher cement content, which favoured water retention. The bleeding capacity 
una rugosidad mayor que incrementa su superficie específica (35), un contenido de polvo del $10 \%$ que incrementa la superficie específica, y además, en estos casos las dosificaciones tenían un contenido de cemento superior, que favoreció la retención del agua. En las Figuras 6.a y 6.b se indican la capacidad y velocidad de exudación, y se observa que a partir de relaciones a/c mayores de 0,51 el proceso de exudación resulta más acentuado en ambas series de hormigones; aunque la velocidad de exudación se acentúa a partir de aproximadamente 0,46 en la Serie $N$.

Por otra parte, otras experiencias (38) muestran que el polvo de roca, con bajo índice de plasticidad, que contienen las arenas de machaqueo puede tener un efecto positivo sobre el estado fresco de los morteros ya que incrementa el volumen de "pasta", separando las partículas y reduciendo la fricción entre ellas. Al considerar al polvo como integrante de la pasta, para el caso de diferentes tipos de arenas de machaqueo, el espesor máximo de pasta del modelo propuesto por F. de Larrard (39, 40) es notablemente diferente, hecho que se vincula a la angularidad las partículas de cada arena.

Resumiendo, las modificaciones en los contenidos de pasta y/o de agua de mezclado de los hormigones con arenas de machaqueo con partículas angulosas y ásperas inciden sobre las propiedades mecánicas y en los mecanismos de transporte del hormigón; aunque las características físicas de las partículas de la arena modificará la interfaz de un modo favorable para la adherencia y el incremento de la tortuosidad de dicha interfaz.

\section{CONCLUSIONES}

Las experiencias realizadas en este programa experimental, orientadas al conocimiento de la influencia de la forma y textura superficial del árido fino en el estado fresco de morteros y hormigones, y especialmente al empleo de arenas de machaqueo en el hormigón, permiten efectuar las siguientes consideraciones:

- La forma y textura superficial de las partículas del árido fino tiene una fuerte influencia sobre el estado fresco de morteros y hormigones, que se manifiesta en incrementos de la demanda de agua entre 25 y 45 $\mathrm{kg} / \mathrm{m}^{3}$ respecto a hormigones con arenas naturales, y depende del tipo de arena de machaqueo empleada. También, los estudios muestran que el volumen de pasta debe ser un $28 \%$ mayor, para disminuir la fricción entre partícula causada por el mayor número de puntos de contacto entre ellas debido a la forma irregular y la textura más áspera de los granos de arena. and rate values given in Figures 6.a and 6.b reveal that with $w / c$ ratios of 0.51 or higher, bleeding was more intense in both series of concretes, although the bleeding rate rose in series $N$ at ratios of higher than around 0.46 .

Furthermore, other studies (38) showed that the low plasticity rock dust present in crushed sands may have a beneficial effect on fresh mortar rheology, for it raises the "paste" volume, separating the particles and reducing the friction between them. When the dust is regarded to be part of the paste, the maximum paste thickness in the model proposed by Larrard $(39,40)$ varies significantly with different types of crushed sand, a finding related to the angularity of the sand particles.

Summing up, modifications in paste or water content when mixing concrete made with crushed sand having rough, angular particles impacts concrete mechanical properties and transport mechanisms, although the physical characteristics of the sand particles increase interface tortuosity and enhance bonding.

\section{CONCLUSIONS}

The conclusions to be drawn from this experimental programme, designed to obtain insight into the effect of fines shape and surface texture on fresh mortar and concrete rheology, in particular in the context of the use of crushed sand in concrete, are listed below.

- The shape and surface texture of fines particles has a heavy impact on concrete and mortar rheology, observable in the increase in water demand by 25 to $45 \mathrm{~kg} / \mathrm{m}^{3}$ in crushed sand compared to natural sand concretes, an effect that depends on the type of crushed sand used. In the former, $28 \%$ more paste (volume) is needed to reduce the inter-particle friction attributable to the larger number of contact points resulting from the irregular shape and rougher texture of the grains of sand. 
- Las experiencias realizadas con hormigones con arena de machaqueo muestran que existe una interrelación entre las principales variables que controlan el estado fresco, relaciones $a / c$ y árido/cemento, y la demanda de agua, de manera similar a lo que ocurre en los hormigones convencionales con arenas naturales.

- La forma y textura de las partículas del árido fino son determinantes sobre el efecto de los aditivos incorporador de aire, plastificante y superfluidificante. Las dosis recomendadas por los fabricantes son efectivas en morteros de arenas naturales, y para el caso de las arenas de machaqueo la eficiencia es menor, siendo necesarias dosis elevadas de los mismos, pero en ningún caso se logra la fluidez o la incorporación de aire de los morteros con arena natural.

- A pesar de la mayor demanda de agua de los hormigones con arena de machaqueo, la presencia de polvo de roca que contienen estas arenas tiene un efecto beneficioso sobre el fenómeno de exudación.
- A relationship can be defined among the main variables that govern fresh concrete rheology, namely the $w / c$ and aggregate/cement ratios and water demand, in much the same way as observed in conventional concretes made with natural sand.

- Fines particle shape and texture have a decisive effect on air-entraining, plasticising and superplasticising admixture performance. Manufacturer-recommended doses of these admixtures are effective in natural sand mortars but less so in crushed sand materials which, even where high doses are used, fail to attain the flowability or air content observed in natural sand mortars.

- Despite the higher water demand in crushed sand concretes, the presence of rock dust in such sand has a beneficial effect on bleeding.

\section{BIBLIOGRAFÍA / BIBLIOGRAPHY}

(1) Rigan, J.: "Dolomitic Aggregates for Concrete", Proc. Colloque International sur les Materiaux Granulaires, Budapest, Hungrie, 9-12 october, 1978, pp. 102-107.

(2) Neville, A.: "Tecnología del Concreto", tomos 1 a 3, Ed. Limusa S.A.: México, 1988.

(3) Kankkunen, H.; Ojanen, P.: "Concrete Rheology and Compaction", Nordic Concrete Research, Publication No 11, 1992, pp. $100-109$.

(4) Kim, J. K.; Lee, C. S.; Park, C. K.; Eo, S. H.: "The Fracture Characteristics of Crushed Limestone Sand Concrete", Cem. and Concr. Res., vol. 27, no 11, 1997, pp. 1719-1729. doi:10.1016/S0008-8846(97)00156-7

(5) Alexander, M. G.; Mindess, S,: "Aggregates in Concrete", Modern Concrete Technology Series, Ed. Taylor \& Francis (London), 2005, $435 \mathrm{p}$.

(6) Westerholm, M.; Lagerblad, B.; Silfwerbrand, J.; Forsseberg, E.: "Influence of Fine Aggregate Characteristics on the Rheological Properties of Mortars", Cement and Concrete Composites, vol. 30, 2008, pp. 274-282. doi:10.1016/j.cemconcomp.2007.08.008

(7) Mehta, P. K.; Monteiro, P.: Concrete. Structures, Properties and Materials, 2nd Edition, Ed. Prentice Hall Inc,: New Jersey, USA, 1993.

(8) Tattersall, G. H.; Banfill, P. F.: The Rheology of Fresh Concrete, Ed. Pitman Publishing Inc, 1st Edition, Massachusetts, USA, 1983.

(9) ACI Committee 211, "Recommended Practice for Selecting Proportions for Normal Weight Concrete", ACI Manual of Concrete Practice, Part 1, Farmington Hill, USA, 1998.

(10) Teychenné, D. C.; Franklin, R. E.; Erntroy, H.: "Design of Normal Concrete Mixes", $2^{\text {nd }}$ edition, Departament of the Environment, Londres, HMSO, 1997.

(11) Popovics, S.: "Concepts for the Prediction of Water Requirement of Concrete", in Properties of Fresh Concrete, Proc. of the RILEM Colloquium no 10, chapter 13, pp. 101-108, Ed. Chapman \& Hall, London, UK, 1990.

(12) Esteves, L. P; Cachim, P. B.; Ferreira, V. M.: "Effect of fine Aggregate on the Rheology Properties of High Performance CementSilica Systems", Construction and Building Materials, In Press, Corrected Proof, Available online 28 December 2009.

(13) Kasemchaisiri, R.; Tangtermsirikul, S.: "A Method to Determine Water Retainability of Porous Fine Aggregate for Design and Quality Control of Fresh Concrete", Construction and Building Materials, vol. 21, Issue 6, June 2007, pp. 1322-1334. doi:10.1016/j.conbuildmat.2006.01.009

(14) Norma ASTM C-128 - 07a. "Standard Test Method for Density, Relative Density (Specific Gravity), and Absorption of Fine Aggregate", 2003.

(15) Norma IRAM 50000. "Cemento. Cemento para Uso General. Composición, Características, Evaluación de la Conformidad y Condiciones de Recepción", 2000.

(16) Norma ASTM C-150, "Standard Specification for Portland Cement", 2009.

(17) Norma IRAM 1681. "Agregado Grueso. Método de Determinación del Factor de Cubicidad", 1981.

(18) Norma IRAM 1687. "Agregados. Parte1: Método de Determinación del Índice de Lajosidad", 1996.

(19) Norma ASTM C-33, "Standard Specification for Concrete Aggregates", 2003. 
(20) Norma IRAM 1604, "Hormigón. Método de Determinación de Exudación", 1991.

(21) Norma BS 812-Part 1, "Methods for Sampling and Testing of Mineral Aggregates, Sands and Filler: Sampling, Shape, Size and Classification, 1985.

(22) Norma IRAM 1505, "Agregados. Análisis Granulométrico", 2003.

(23) Norma IRAM 1540, "Agregados. Método de Determinación del Material Fino que Pasa por el Tamiz IRAM 75 m por Lavado", 1986.

(24) Norma IRAM 1520, "Agregados finos. Métodos de Laboratorio para la Determinación de la Densidad Relativa Real, de la Densidad Relativa Aparente y de la Absorción de Agua", 2002.

(25) Norma IRAM 1548, "Agregados. Determinación de la Densidad a Granel y de los Espacios Vacíos", 2003.

(26) Nagaraj, T. S.; Shashiprakash, S. G.; Raghu Prasad, B. K.: "Reproportioning Concrete Mixes", ACI Materials Journal, 1993, vol. 90, No 1.

(27) Nagaraj, T. S.; Banu, Z.: "Generalization of Abrams' Law", Cem. and Concr. Res., vol. 26, no 6, pp. 933-942, 1996. doi:10.1016/0008-8846(96)00065-8

(28) Rixom, R.; Mailvaganam, N.: Chemical Admixtures for Concrete, $3^{\text {rd }}$ edition, Ed. E. \& F. N. Spon Ltd, 1999.

(29) Ramachandran, V. S. et al:: Concrete Admixtures Handbook. Properties, Science, and Technology, 2nd Edition, Ed. V. S. Ramachandran, Noyes Publications, 1995.

(30) Donza, H. A.; Cabrera, O. A.: "The Influence of Kind of the Fine Aggregate on the Mechanical Properties of High Strength Concrete", Proc. 4th International Symposium on Utilization of High-Strength/High-Performance Concrete, 1996, vol. 2, pp. 153-160 - Paris, Francia.

(31) Norma IRAM 1679, "Cemento de Albañilería. Métodos de Ensayo", 1970.

(32) Norma IRAM 1634, "Cemento Pórtland. Método para la Determinación del Contenido de Aire en Morteros", 1963.

(33) Cabrera, O. A.; Casinelli, G.; Donza, H. A.; Menéndez, G.: "Hormigones con Arena de Dolomías Trituradas", Revista de ASAGAI (Asociación Argentina de Geología Aplicada a la Ingeniería), no 14, 2000, pp. 6-11.

(34) Domone, P. L.; Soutsos, M. N.: "An Approach to the Proportioning of High-Strength Concrete Mixes", Concrete International, vol. $16, \mathrm{n}^{\circ} 10,1994$, pp. 26-31.

(35) Ozol, M. A.: "Test and Properties of Concrete Aggregates", Significance of Tests and Properties of Concrete and Concrete-making Materials, 1978, pp. 584-628.

(36) Toralles Carbonari, B.; Agulló Fité, L.; Gettu, R.: "Procedimiento para la Optimización de Hormigones de Altas Prestaciones", Hormigón y Acero, 2do. trimestre, 1998, pp. 19-30.

(37) Popovics, S.: "Segregación y Exudación", Proc. of RILEM Seminar on Fresh Concrete, vol. 3, 1973.

(38) Cabrera, O. A.; Traversa, L. P.; Ortega, N. F.: "Fluidez de Morteros Cementíceos con Arenas Machacadas", aceptado para su publicación en la Revista Mater. Construcc., vol. 60, № 300, pp. 115-130, octubre-diciembre 2010, ISSN: 0465-2746 e ISSN: 1988-3226, doi: 10.3989/mc.2010.50909

(39) De Larrard, F.; Sedran, T.: "Optimization of Ultra-High-Performance Concrete by the Use of a Packing Model", Cem. and Concr. Res, vol. 24, no 6, pp. 997-1009, 1994. doi:10.1016/0008-8846(94)90022-1

(40) De Larrard, F.; Belloc, A.: "The Influence of Aggregate on the Compressive Strength on Normal and High-Strength Concrete", $A C I$ Materials Journal, vol. 94, no 5, 1997, pp. 417-426. 